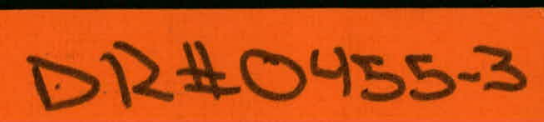

DOE/MC/14322-1577

(DE84009261)

\title{
NYU-DOE PRESSURIZED FLUIDIZED BED COMBUSTOR FACILITY
}

By

V. Zakkay

A. Kolar

K. Sellakumar

S. Srinivasaragavan

G. Miller

S. Panunzio

A. Joseph

C. Sundaresan

January 1983

Work Performed Under Contract No.: DE-AS21-80MC-14322

For

U. S. Department of Energy

Office of Fossil Energy

Morgantown Energy Technology Center

Morgantown, West Virginia

By

New York University

Faculty of Arts and Science

Department of Applied Science

TECHNICAL INFORMATION CENTER OFFICE OF SCIENTIFIC AND TECHNICAL INFORMATION UNITED STATES DEPARTMENT OF ENERGY 


\section{DISCLAIMER}

This report was prepared as an account of work sponsored by an agency of the United States Government. Neither the United States Government nor any agency Thereof, nor any of their employees, makes any warranty, express or implied, or assumes any legal liability or responsibility for the accuracy, completeness, or usefulness of any information, apparatus, product, or process disclosed, or represents that its use would not infringe privately owned rights. Reference herein to any specific commercial product, process, or service by trade name, trademark, manufacturer, or otherwise does not necessarily constitute or imply its endorsement, recommendation, or favoring by the United States Government or any agency thereof. The views and opinions of authors expressed herein do not necessarily state or reflect those of the United States Government or any agency thereof. 


\section{DISCLAIMER}

Portions of this document may be illegible in electronic image products. Images are produced from the best available original document. 


\title{
DISCLAIMER
}

\begin{abstract}
This report was prepared as an account of work sponsored by an agency of the United States Government. Neither the United States Government nor any agency thereof, nor any of their employees, makes any warranty, express or implied, or assumes any legal liability or responsibility for the accuracy, completeness, or usefulness of any information, apparatus, product, or process disclosed, or represents that its use would not infringe privately owned rights. Reference herein to any specific commercial product, process, or service by trade name, trademark, manufacturer, or otherwise does not necessarily constitute or imply its endorsement, recommendation, or favoring by the United States Government or any agency thereof. The views and opinions of authors expressed herein do not necessarily state or reflect those of the United States Government or any agency thereof.
\end{abstract}

This report has been reproduced directly from the best available copy.

Available from the National Technical Information Service, U. S. Department of Commerce, Springfield, Virginia 22161.

Price: Printed Copy A04

Microfiche A01

Codes are used for pricing all publications. The code is determined by the number of pages in the publication. Information pertaining to the pricing codes can be found in the current issues of the following publications, which are generally available in most libraries: Energy Research Abstracts (ERA); Government Reports Announcements and Index (GRA and I); Scientific and Technical Abstract Reports (STAR); and publication NTIS-PR-360 available from NTIS at the above address. 


\title{
NYU-DOE PRESSURIZED FLUIDIZED BED COMBUSTOR FACILITY
}

\author{
By \\ V. Zakkay \\ A. Kolar \\ K. Sellakumar \\ S. Srinivasaragavan \\ G. Miller \\ S. Panunzio \\ A. Joseph \\ C. Sundaresan
}

January 1983

Work Performed Under Contract No.: DE-AS21-80MC-14322

\author{
For \\ U. S. Department of Energy \\ Office of Fossil Energy \\ Morgantown Energy Technology Center \\ P.O. Box 880 \\ Morgantown, West Virginia 26505
}

By

New York University

Faculty of Arts and Science

Department of Applied Science

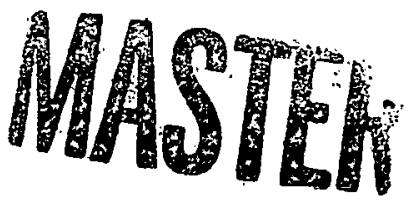


‘

THIS PAGE

\section{WAS INTENTIONALLY LEFT BLANK}


4

Data Acquisition 


\section{SUMMARY}

New York University (NYU), under a Department of Energy (DOE) Contract, has designed and constructed a sub-pilot scale Pressurized Fluidized-Bed Combustor (PFBC) Facility at the Antonio Ferri Laboratories, Westbury, Long Island. The basic feature of this Experimental Research Facility is a well-instrumented, 30-inch diameter coal combustor capable of operating up to $10 \mathrm{~atm}$ and provided with a liberal number of ports, making it a versatile unit for study of fundamental in-bed phenomena. Additionally, the overall design features make it a flexible facility for solving a variety of industrial research problems. The main objectives of the facility are two-fold: 1) to perform research in important areas of Pressurized Fluidized-Bed Combustion like low-grade fuel combustion under pressure, and 2) to provide the PFBC community with a experimental research tool for basic and applied research in order to accelerate the commercialization of this technology.

New York University will initially test the facility of burning low-grade fuels under pressure. During the test program, emphasis will be placed on burning North Dakota lignite under pressures up to $7 \mathrm{~atm}$. The performance of 1 ignite with regard to its feeding, combustion efficiency, sulfur adsorption and sorbent requirements will be investigated.

This report describes the various systems of the PFBC facility and operating procedures, and presents an outline of the test program planned for the facility. Other details are provided in the Equipment and Maintenance Manual, Test Program and Data Acquisition Manual, and Training Manual. 


\section{THIS PAGE WAS INTENTIONALLY LEFT BLANK}




\section{Introduction}

Fluidized-Bed Coal Combustion has emerged as an effective technology for utilizing coal in a thermally efficient, environmentally acceptable and economically viable manner. Further, the many advantages it exhibits over conventional pulverized coal combustion has made it an exciting and potentially more rewarding technology. The importance of research in this fast developing area of coal utilization is indicated by the University and industrial projects in progress, from laboratory scale to pilot plant scale, under the sponsorship of the Department of Energy.

Atmospheric Fluidized-Bed Combustion technology has reached a point of commercialization, mainly as a result of its simplicity and the intensive research in the fundamental in-bed processes. Additionally, its wide application-potential for large-scale electric power generation as well as small-scale steam generation for industrial process heat has enhanced its claim for early commercial use. On the other hand, Pressurized Fluidized-Bed Combustion technology is only in an advanced developmental stage. The complexities brought about by high pressure/combined cycle operation in terms of understanding the in-bed processes and developing suitable high-temperature, high pressure devices, coupled with the more restricted, but important, area of application viz., electric power generation, have slowed the pace of development.

New York University (NYU) initiated a PFB Combustion program in 1976 under contract with ERDA (now DOE). A one-foot gas fired (1 to 7 ata) facility and a one-foot atmospheric coal-fired facility were designed, constructed and operated during a four-year period 1976-1980. Experimental data was acquired to determine basic fluidized-bed behavior in terms of heat transfer, bed expansion and particle attrition as functions of bed temperature, pressure, height, fluidizing velocity and particle size. In 1980, it was recognized that a concerted effort was needed to accelerate the development of PFBC technology in this country and that a flexible, experimental research facility was an essential starting point for such an effort. Such a facility would provide easy access to the PFB research community to study the various fundamental and applied problems of an industrial nature in a facility of reasonable size. NYU, under contract with DOE, initiated the design and construction of a 30 inch diameter PFBC facility in Westbury, Long Island, in August 1980 with a two-fold objective: 1) to perform research in important areas of PFBC and, 2) to provide a sub-pilot scale research facility to the PFB community for its use. 
The PFB facility is designed to study low-grade fuel combustion under pressure. Specifically, North Dakota lignite will be burned to determine its performance with regard to its feeding, combustion efficiency, sulfur adsorption, and sorbent requirements. This manual presents a description of the NYU-DOE PFBC facility and outlines the Test Program. The operations procedures and safety provisions are also presented. 


\section{Design and Performance Data}

The operating and design point conditions and the analysis of solid fuels and sorbents are given below:

\section{Facility Operating Conditions}

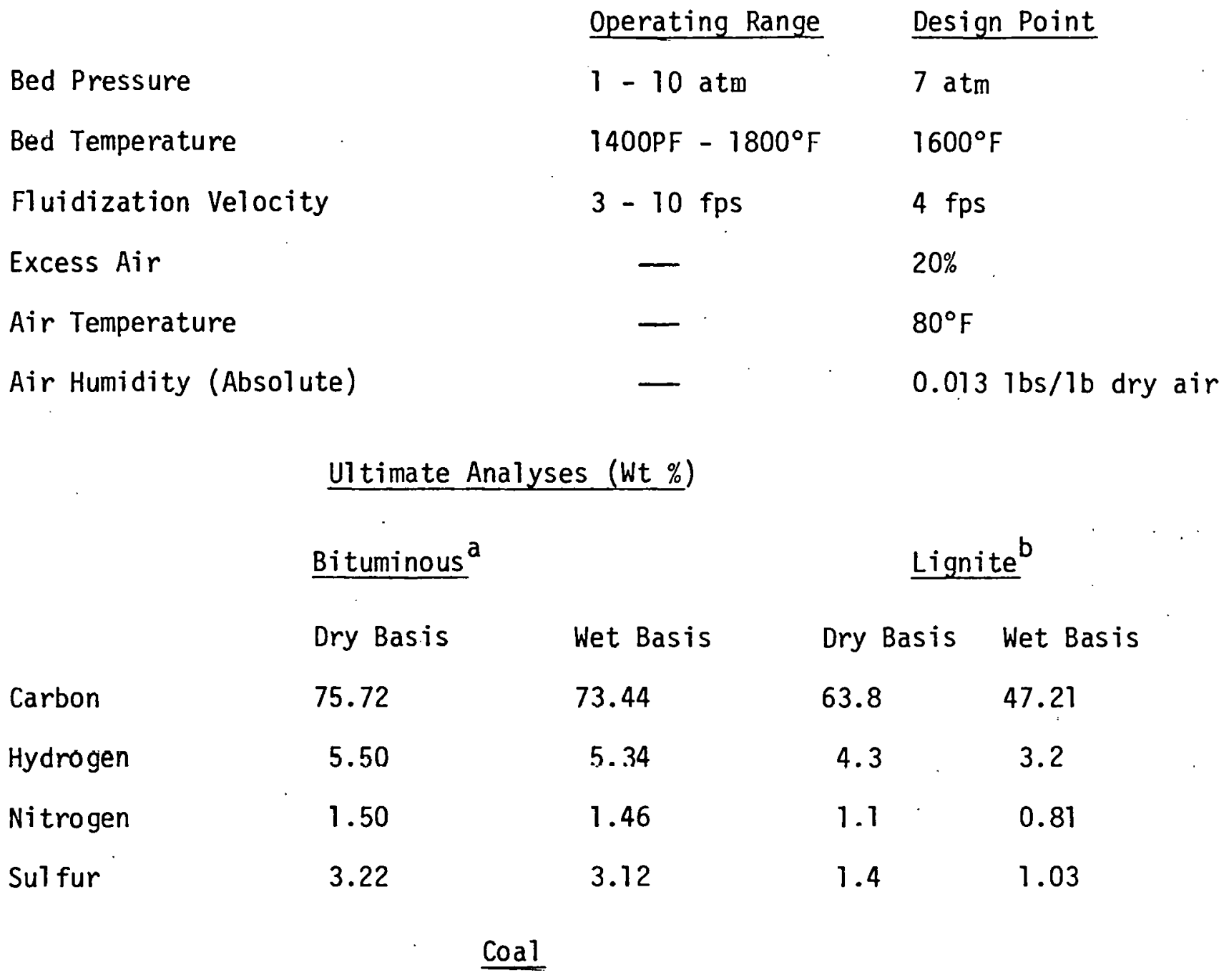
a) Pittsburgh Seam, Valley Camp Coal Company, West Virginia
b) North Dakota, Beulah Mine 


\section{Ultimate Analyses (Wt \%) Cont'd}

\section{Bituminous}

Dry Basis

Oxygen

Chlorine

Ash

Mo is ture

Heating Value
6.29

0.09

7.68

$-$

$13800 \mathrm{Btu} / \mathrm{Tb}$

Proximate Analyses (Wt \%)

6.10

0.087

7.45

3.00

\section{Lignite}

Wet Basis Dry Basis Wet Basis

18.2

13.47

11.2

8.29

26.40

26.00
Bituminous

36.55

3

7.45

53.00
Lignite

25.20

26.0

8.29

40.51

\section{Fixed Carbon}

Sorbent

Limestone (Wt \%) ${ }^{a} \quad$ Dolomitc (Wt \%)

$\mathrm{Cd} \mathrm{CO}_{3}$

94.04

54.2

$\mathrm{Mg} \mathrm{CO} 3$

1.46

44.8

Inert
a - Newton, New Jersey
b - Pfizer 1337, Ohio 


\section{Description of Facility}

The facility is classified into eight systems as shown in Table 3-1. The individual systems are described below. Figure 3-1 is a line diagram of the facility. Figure 3-2 an artist's conception.

\subsection{Preheat System}

Preheat of bed material at start-up is performed by two systems, a primary gas preheat and a secondary kerosene preheat.

The gas preheat is accomplished by a North American combustion system consisting of two $0.43 \times 106 \mathrm{Btu} / \mathrm{hr}$ gas burners which are positioned below the grid in the lower plenum chamber. Utilizing a shallow bed, ( $\simeq 2 \mathrm{ft}$ static bed height) and maintaining the gas temperature in the lower plenum betweel $1200^{\circ} \mathrm{F}$ and $1600^{\circ} \mathrm{F}$, the bed material is heated to $800^{\circ} \mathrm{F}$ in about an hour.

At a bed temperature of $800^{\circ} \mathrm{F}$, the kerosene preheat system is actuated and the fuel is injected into the bed where combustion takes place. At this point, both the kerosene and gas burners are on. Once the bed temperature reaches $1200^{\circ} \mathrm{F}$ (in about 15 minutes), the gas burner is shut off and coal feeding is started. Kerosene injection is turned off once the bed reaches a temperature of $1400^{\circ} \mathrm{F}$. The details of the preheat systems are presented in Table 3-2, and Figs. 3-3 and 3-4.

\subsection{Air System}

The air system is capable of supplyiny compresscd air over the whole range of pressures $(1-10 \mathrm{~atm})$ and velocities (3-10 fps). The compressors aiso meet the requirements of auxilliary systems, viz., solid handling lockhoppers, tempering air for pressure control, utility air, instruments, sorbent transport, purging, etc.

Additional air supply is available from an existing air storage bank. The available air capacity is 1000 cubic feet at 2000 psig. This air can be used for short duration runs (less than 4 hours) and low pressure operation. 


\section{Table 3-1 \\ System Classification}

1. Preheat System: preheat chamber, gas preheat, kerosene preheat.

2. Air System: compressors, air chamber, fluidizing and auxilliary air lines.

3. Hcat Exehanger System.

4. Combustor System: air distributnr, main combustor, free-board, top cone, top tee.

5. Flue Gas System: primary cyclone, secondary cyclone, trickle valve, cyclone ash system, pressure let-down sys tem.

6. Material Handling System: coal and sorbent storage and conveying, ash removal.

7. Material Feeding System: coal and sortenl bins, lockhoppers, feeding pipes.

8. Instrumentation and Controls 


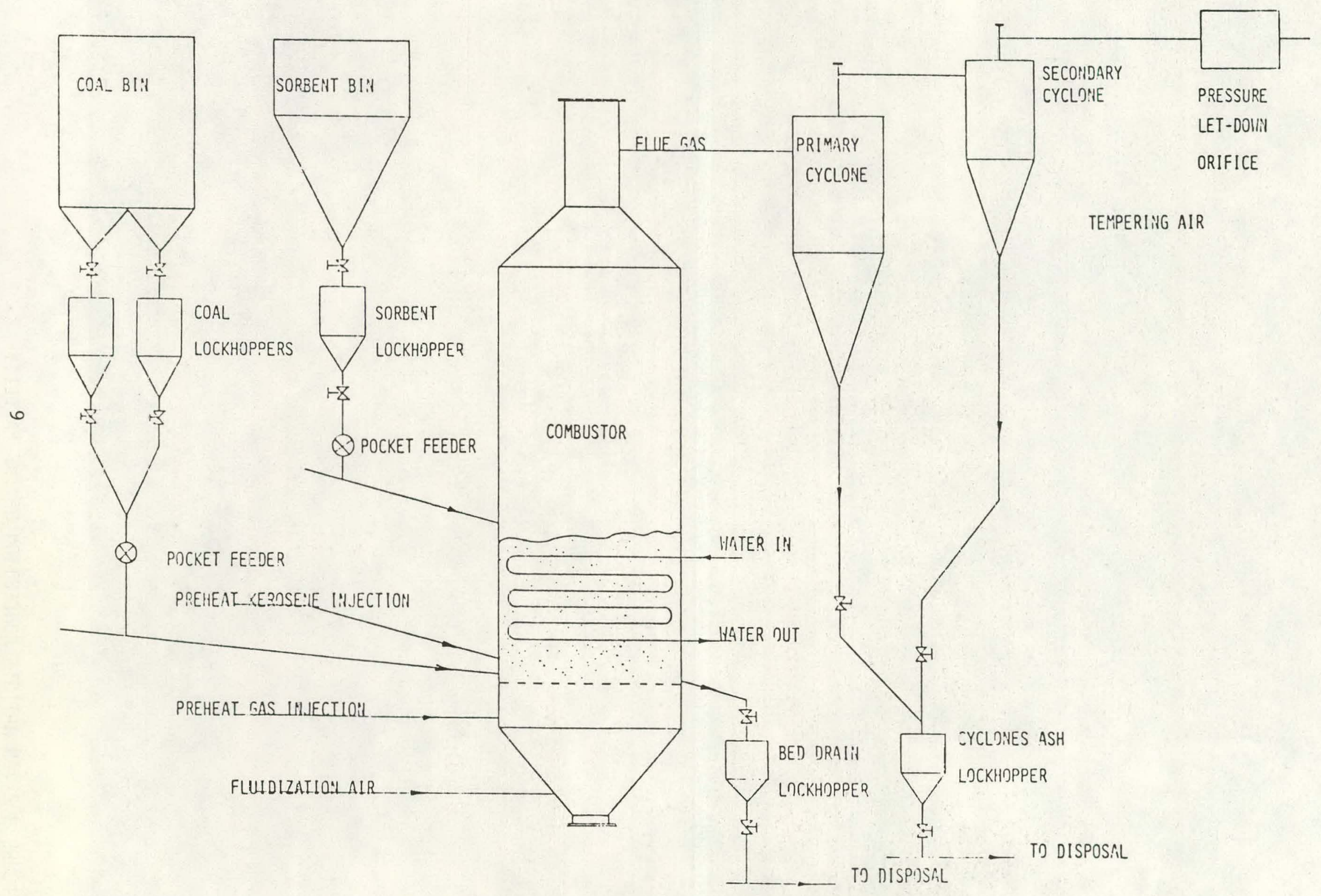

FIGURE 3.1 NYU-DOE PRESSURIZED FLUIDIZED BED COMBUSTOR FACILITY 


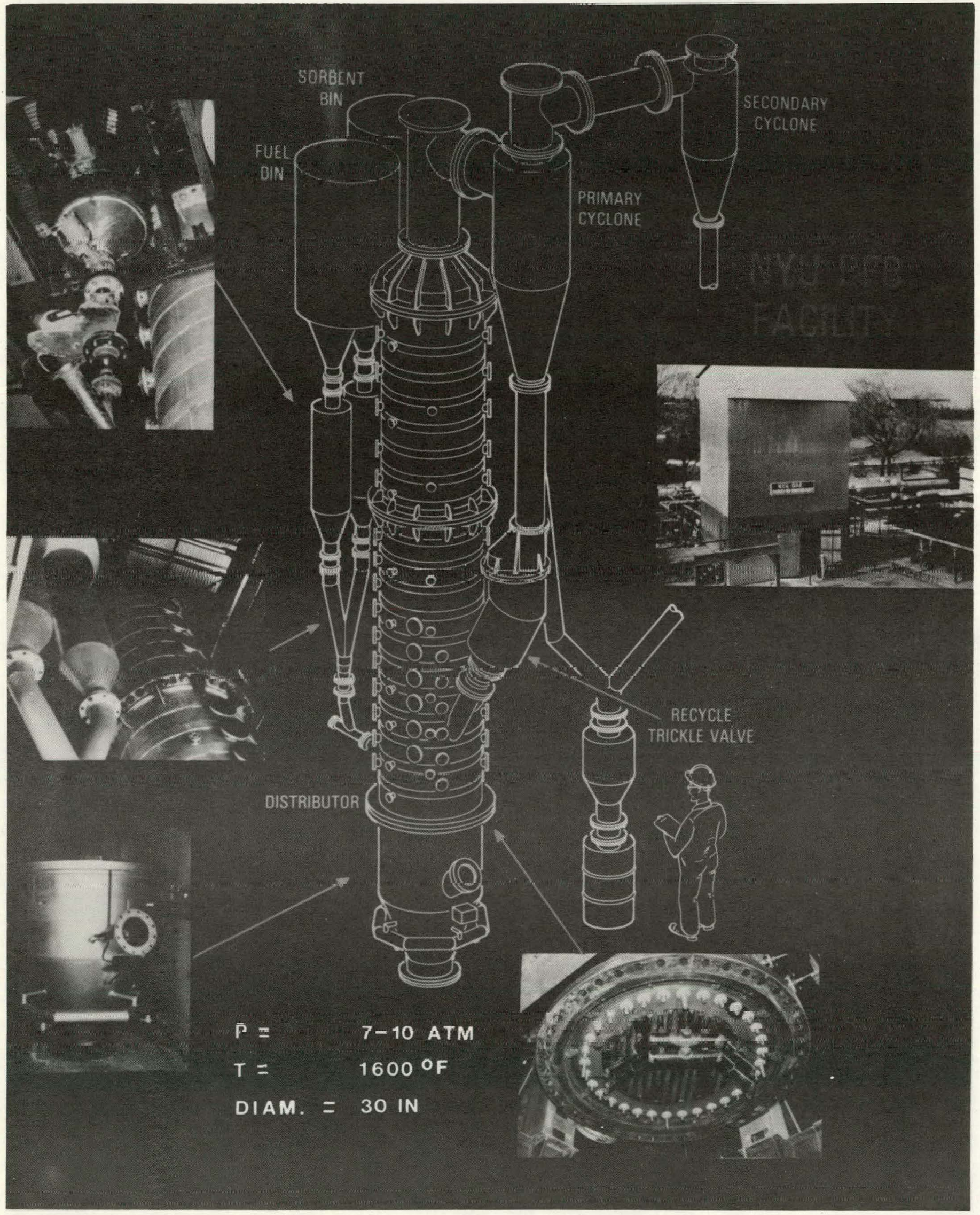

FIGURE 3.2 AN ARTISTS CONCEPTION OF THE FACILITY 
Table 3-2

Preheat System

Number of Gas Burners:

Two

Total Gas Burners Capacity

$0.86 \times 10^{6} \mathrm{Btu} / \mathrm{hr}$

Fuel :

Methane or Propane

Gas Pressure:

2-50 psig

Gas Flow:

$860 \mathrm{cfh}$ of Methane for two burners

Kerosene Burner Capacity:

$4.3 \times 1.0^{6} \mathrm{Btw} / \mathrm{hr}$

Kerosene $\mathrm{Hr}$ Rate:

$239 \mathrm{lb} / \mathrm{hr}$

Location of Injector:

11 inches above grid

Kerosene Inlet Diameter:

$1 / 16$ inch

Time Taken to Heat the Bed from Ambienl to $800^{\circ} \mathrm{F}$ :

58 min

(No Water Flow Through Heat Exchanger Tubes)

Time Taken to Heat the Bed from $800^{\circ} \mathrm{F}$ to $1200^{\circ} \mathrm{F}$ :

15 minutes (without gas burners)

6.6 minutes (with gas burners) 


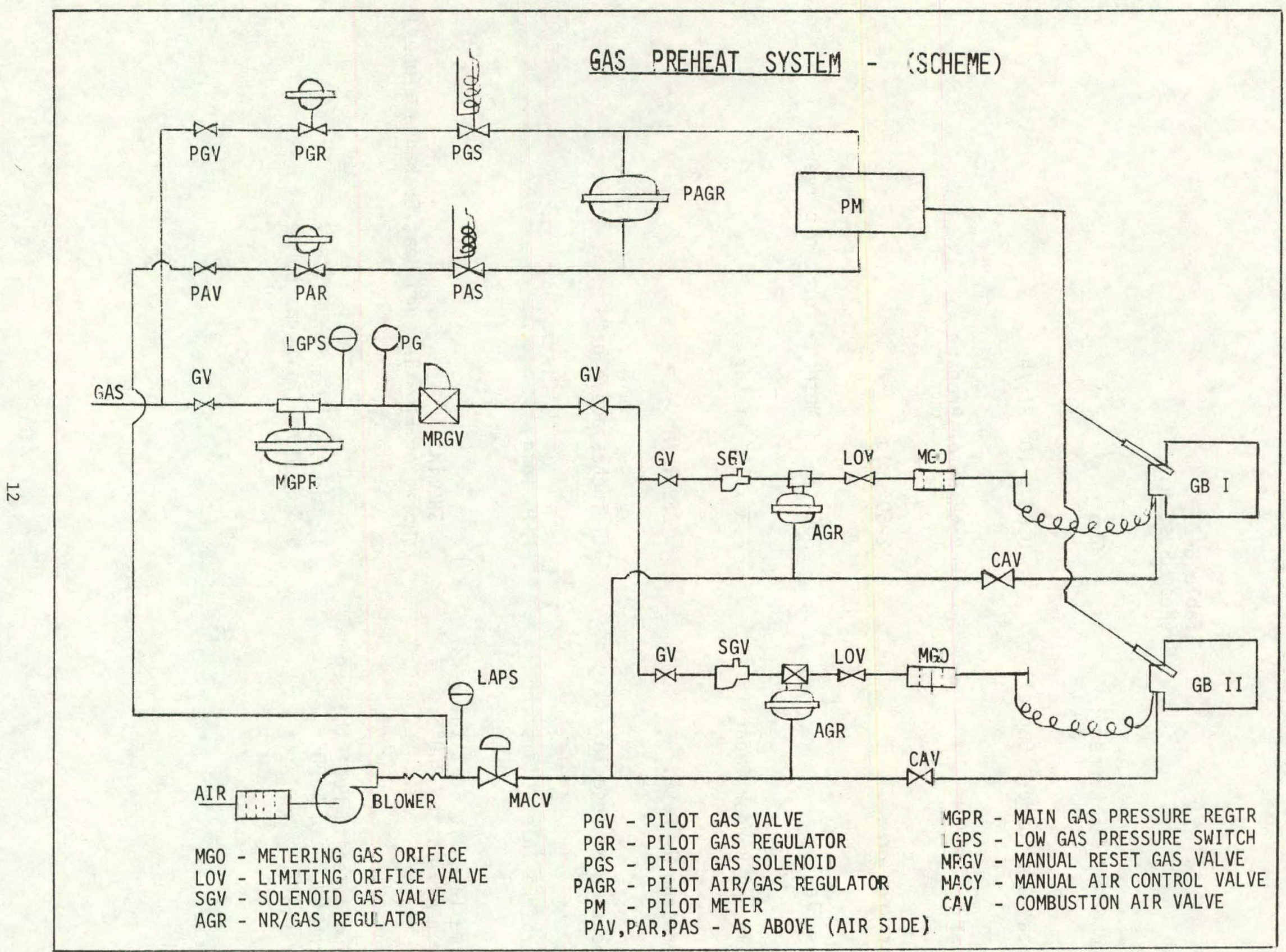

FIGURE 3.3 GAS PREHEAT JYSTEM 


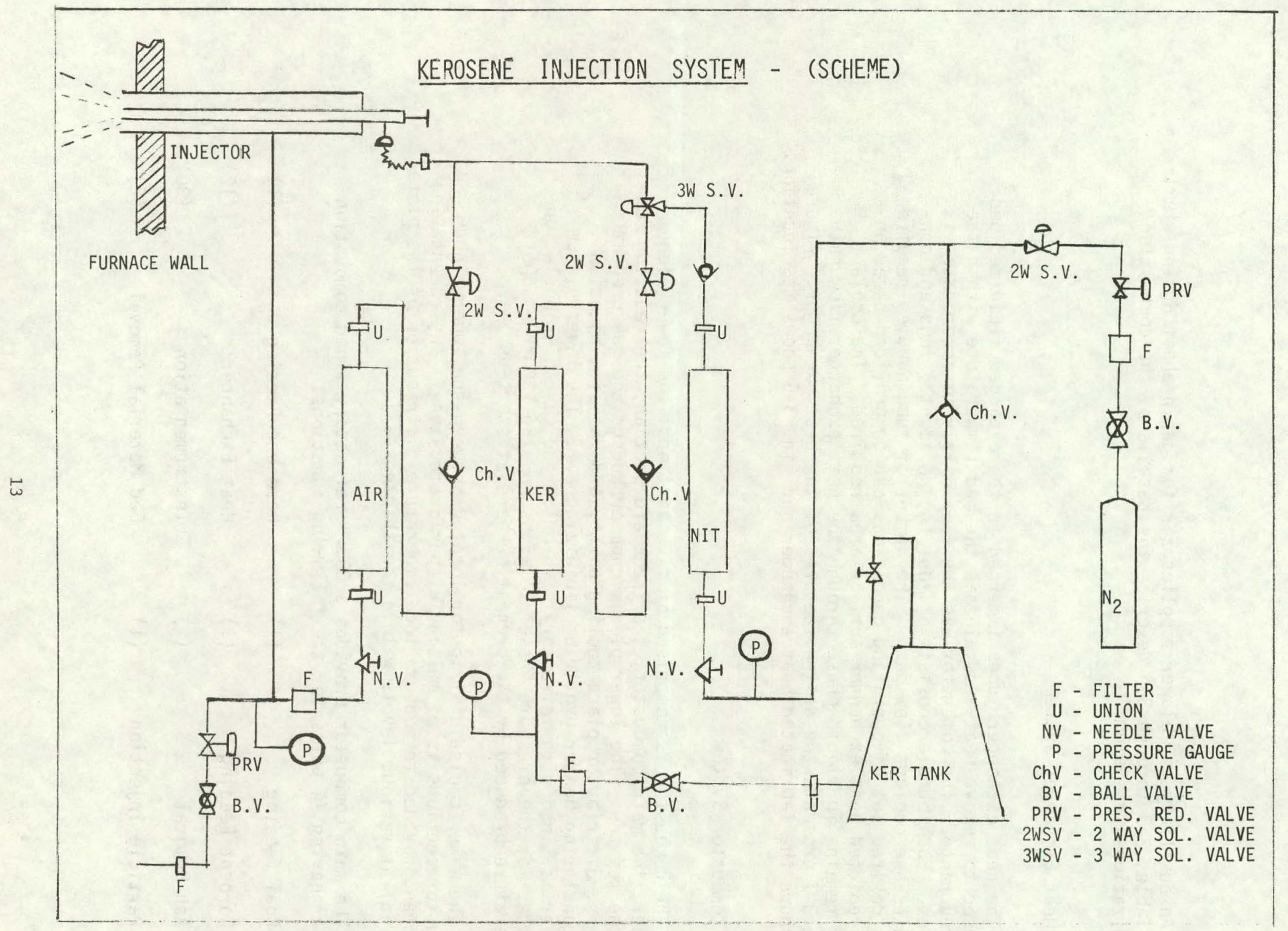

FIGURE 3.4 KEROSENE PREHEAT SYSTEM 
An auxiliary air blower supplies air for gas preheat during start up. Tables 3-3 through 3-6 describe the details of the combustion/ fluidization air system.

\subsection{Heat Exchanger System}

The heat exchanger tubes immersed in the expanded fluidized bed are used to remove heat and maintain the bed temperature within the desired range. The combustor has the flexibility to accomodate six bundles. Each bundle consists of four (4) horizontal rows and constitutes one coolant flow path. The number of tube bundles required for a desired set of operating conditions can be provided based on the predicted heat exchanger surface area required. The coolant water remains in liquid phase through the heat exchanger flow path. Table 3-7 presents the design features of the heat exchanger. Figure 3-5 shows the fabricated heat exchanger and Fig. 3-6 shows its location.

\subsection{Combustor System}

The combustor is comprised of five sections: the lower plenum chamber, the main combustor, the freeboard section, the reducing cone and the top tee. The lower plenum chamber houses the gas preheat burners, distributor place cooling ports, and the air injection octagonal ring header providing fluidizing air. The lower plenum chamber is lined with refractory fire brick and castable insulation in order for the pressure vessel to withstand the $1200^{\circ} \mathrm{F}-1600^{\circ} \mathrm{F}$ temperature produced by the preheat burners at start-up.

The water cooled distributor located between the lower plenum and combustor sections is of multihole (perforated)type. Instrumentation has been provided to measure the temperature distribution of the plate material at various levels within the thickness.

The main combustor provides a $30.7^{\prime \prime}$ refractory lined combustion chamber having 74 ports for the following functions:

$\begin{array}{lll}\text { Coal Feeding } & (1) & \text { Kerosene Feeding } \\ \text { Sorbent Feeding } & (1) & \text { Heat Exchanger } \\ \text { Ash Removal } & (1) & \text { Instrumentation } \\ \text { Particle Injection } & (1) & \text { Bed Material Removal }\end{array}$



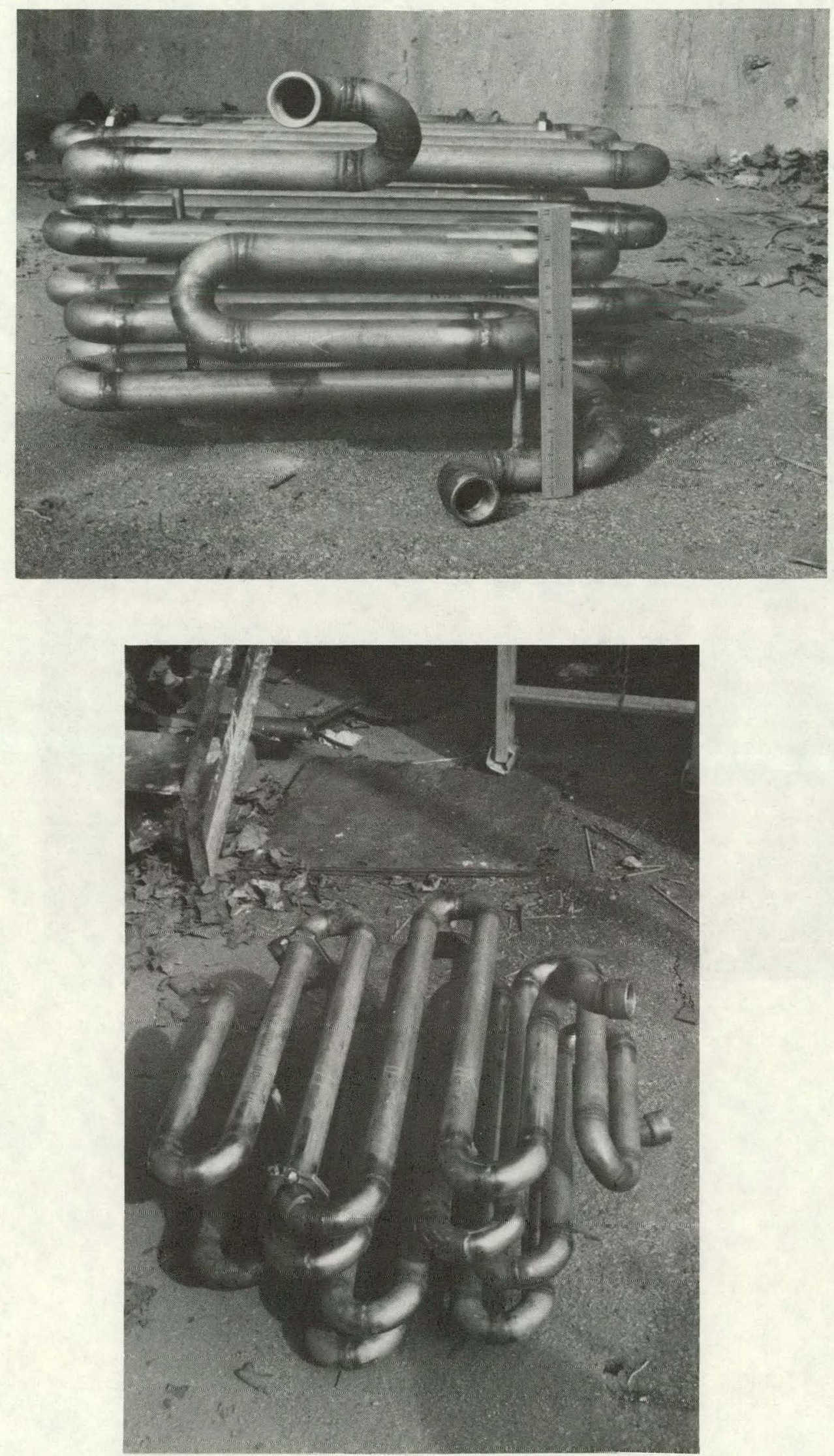

FIGURE 3.5 HEAT EXCHANGER BUNDLE 


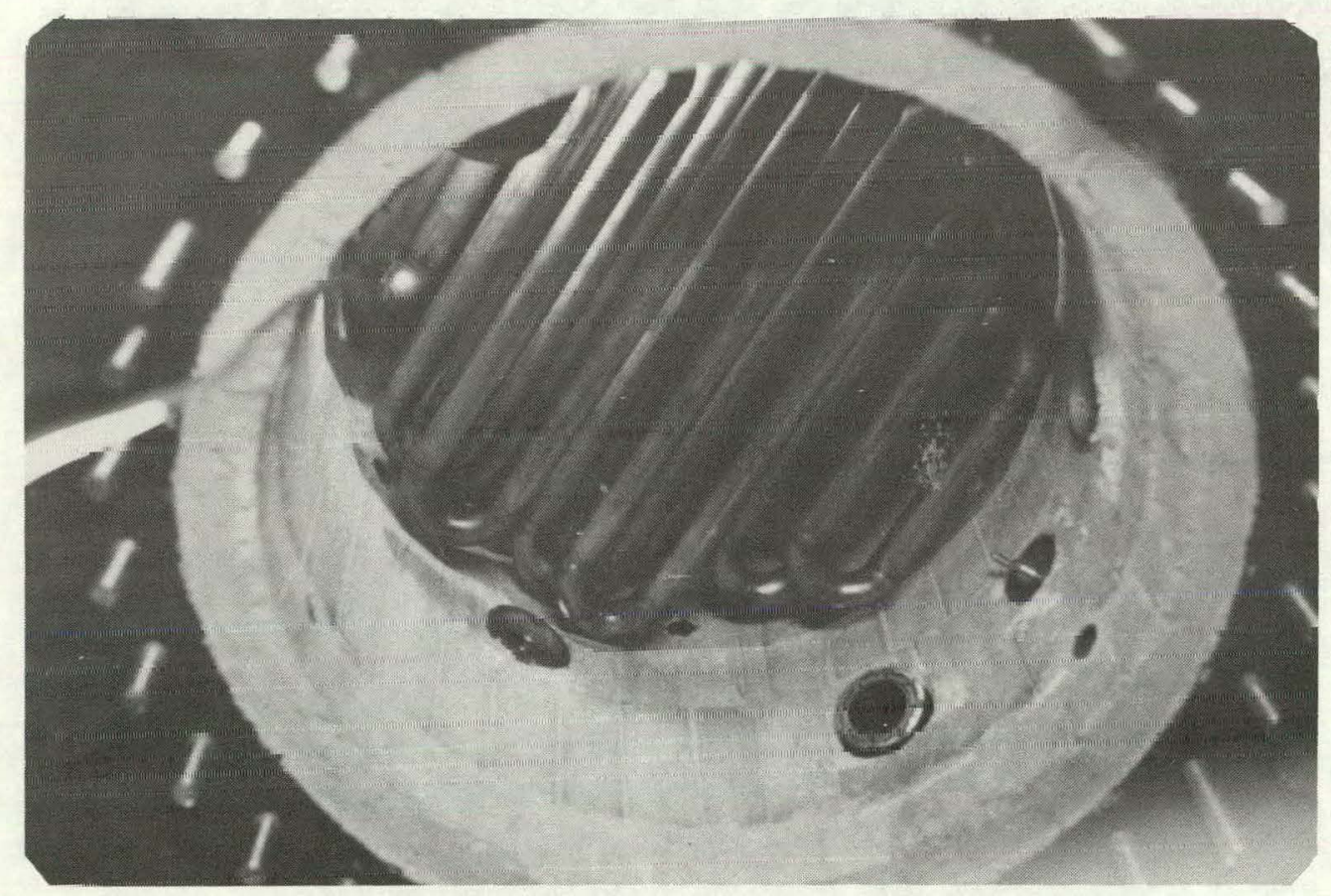

FIGURE 3.6 HEAT EXCHANGER LOCATION 
Table 3-3

Air Header System

Air Header Size:

Fluidizing Air Distribution Ring Size:

Total Number of Air Inlets

into Air Plenum:
24 in 0.D., 144 in Long, 37 cubic ft capacity

$59 / 16$ in

8 


\section{Table 3-4 \\ Air Compressor System}

Type:

Number:

Cápacity:
Gardner-Denver

2

$1600 \mathrm{cfm}$ at 100 psig and $145^{\circ} \mathrm{F}$ 
Table 3-5

Combustion Air. System

\begin{tabular}{|c|c|c|c|c|c|c|}
\hline $\begin{array}{l}\text { SERIAL } \\
\text { NO' }\end{array}$ & $\begin{array}{l}\text { NAME OF. } \\
\text { CIRCUIT }\end{array}$ & $\begin{array}{l}\text { LINE } \\
\text { SIZE } \\
\text { (IPS) }\end{array}$ & $\begin{array}{l}\text { OPERATING } \\
\text { PRESSURE } \\
\text { (PSIG,MAX) }\end{array}$ & $\begin{array}{l}\text { AIR } \\
\text { TEMP } \\
\left({ }^{\circ} \mathrm{F}\right)\end{array}$ & 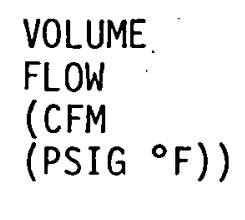 & $\begin{array}{l}\text { MASS } \\
\text { FLOW } \\
(1 \mathrm{~b} / \mathrm{hr})\end{array}$ \\
\hline 1 & Blower Air & 5 & 3 & 60 & 1030 & 4721 \\
\hline 2 & Fluidizing Air & 5 & 125 & 145 & $\begin{array}{l}3435 \\
(0 ; 32)\end{array}$ & 16502 \\
\hline 3 & $\begin{array}{l}\text { Coal Transport } \\
\text { Air }\end{array}$ & $2 \frac{1}{2}$ & 125 & 145 & $\begin{array}{l}36.10 \\
(125 ; 145)\end{array}$ & \\
\hline 4 & Shell Cooling & 2 & 125 & 145 & $(b)$ & (b) \\
\hline
\end{tabular}

a) IPS $=$ İron P̄ipe Size

b). To be determined during commissioning 
Table 3-6

Auxiliary Air System

\begin{tabular}{|c|c|c|c|c|c|c|}
\hline $\begin{array}{l}\text { SERIAL } \\
\text { NO }\end{array}$ & $\begin{array}{l}\text { NAME OF } \\
\text { CIRCUIT }\end{array}$ & $\begin{array}{l}\text { LINE } \\
\text { SIZE } \\
\text { (IPS) }\end{array}$ & $\begin{array}{l}\text { OPERATING } \\
\text { PRESSURE } \\
\text { (PSIG,MAX) }\end{array}$ & $\begin{array}{l}\text { AIR } \\
\text { TEMP } \\
\left({ }^{\circ} \mathrm{F}\right)\end{array}$ & $\begin{array}{l}\text { VOLUME } \\
\text { TEMP } \\
(\mathrm{cfm} \text { (psig, } \\
\left.{ }^{\circ} \mathrm{F}\right) \text { ) }\end{array}$ & $\begin{array}{l}\text { MASS } \\
\text { FLOW } \\
(1 \mathrm{~b} / \mathrm{hr})\end{array}$ \\
\hline 4 & $\begin{array}{l}\text { coal Lockhupper } \\
\text { pressurizing air }\end{array}$ & $3 / 4$ & 125 & 145 & $\begin{array}{l}4.215 \\
(125 ; 145)\end{array}$ & 157 \\
\hline 5 & $\begin{array}{l}\text { Particle Removal } \\
\text { Probe }\end{array}$ & $3 / 4$ & 125 & 145 & $\begin{array}{l}6.48 \\
(88.2 ; 145)\end{array}$ & 177 \\
\hline 6 & $\begin{array}{l}\text { Pressure Taps } \\
\text { Purge Nir }\end{array}$ & $3 / 4$ & 125 & 145 & $\begin{array}{l}4.215 \\
(125 ; 145)\end{array}$ & 157 \\
\hline 7 & $\begin{array}{l}\text { Kerosene Inject- } \\
\text { ion Probe }\end{array}$ & 1 & 125 & 145 & $\begin{array}{l}20.66 \\
(12.93 ; 145)\end{array}$ & 767 \\
\hline 8 & Instrumentation & 1 & 125 & 145 & $\begin{array}{l}12.24 \\
(125 ; 145)\end{array}$ & 454.5 \\
\hline 9 & Utilities & $3 / 4$ & 125 & 145 & $\begin{array}{l}4.215 \\
(125 ; 145) .\end{array}$ & 157 \\
\hline 10 & Spare & $3 / 4$ & 125 & 145 & $\begin{array}{l}4.215 \\
(125 ; 145)\end{array}$ & 157 \\
\hline 11 & $\begin{array}{l}\text { Bed Drain Lock- } \\
\text { hopper Air Line }\end{array}$ & $3 / 4$ & 125 & 145 & $\begin{array}{l}l \\
(125 ; 145)\end{array}$ & 37 \\
\hline 12 & $\begin{array}{l}\text { Sorbent Trans- } \\
\text { port. Air }\end{array}$ & 3 & 125 & 145 & $\begin{array}{l}143.63 \\
(125 ; 145)\end{array}$ & 5328 \\
\hline 13 & $\begin{array}{l}\text { Sorbent Lock- } \\
\text { hopper Air }\end{array}$ & $3 / 4$ & 125 & 145 & $\begin{array}{l}2.114 \\
(125 ; 145)\end{array}$ & 78.5 \\
\hline 14 & $\begin{array}{l}\text { Particle Re- } \\
\text { injection Line }\end{array}$ & 2.5 & 125 & 145 & - & - \\
\hline
\end{tabular}


Table 3-7

HX Design Features.

Material :

Size:

No. of Bundles Installed:

No. of Rows/Bundle:

Horizontal Pitch:

Vertical Pitch:

External Wetted Area:

Total HX Wetted Area:

Length of Tubing

Inside Area:

Tube Cross-sectional Area:

Distance Between Tube Walls

(Horizontal):

Distance Between Tube Walls

(Diagonal):

Distance Between Tube Wall and Brick Wall:

Solidity (Volumetric):

Solidity (Area):

$$
\begin{aligned}
& S_{H} / O D \\
& S_{V} / O D
\end{aligned}
$$

Water Flow:
316 S.S.

$11 / 4$

3

4

$\mathrm{S}_{\mathrm{H}}=3.75 \mathrm{in}$

$S_{V}=3.0$ in

$22.83 \mathrm{ft}^{2} /$ bundle

$137 \mathrm{ft}^{2}$

$52.5 \mathrm{ft} /$ bundle

$19 \mathrm{ft}^{2} /$ bundle

1.495 in $^{2}$

2.09 in

1.91 in

1 in Min

$7.6 \%$

35.0

$3.75 / 1.66$

$2 / 1.66$

$23 \mathrm{gpm} /$ bundle at $50 \mathrm{psig}$ 
Visualization Windows

Spare Windows
(8)
Vessel Cooling Tube Inlet and Outlet

Pressure Tap

The freeboard section is similarly refractory lined to $30.7^{\prime \prime}$ diameter and is designed with ports for instrumentation and freeboard heat exchangers.

The cone and top tee sections are also lined with refractory. The cone has a pressure relief patch to protect against over-pressurization. The top tee provides the connection to the cyclone system. Figure 3-7 shows the distributor plate and Table 3-8 describes the details of the cumbustur. system.

\subsection{Flue Gas System}

The flue gases exiting the combustor pass through a particulate removal system and a pressure let-down system before exhausting into the atmosphere. The particulate removal system is comprised of two cyclones. A 24 inch diameter primary cyclone removes large particles from the flow gases which may be either dropped into the cyclone ash lockhopper for disposal or reinjected back into the combustor via a trickle valve. A 16 inch diameter secondary cyclone cleans the flue gases further by removing particles less than about $20 \mu$. Acceptably clean gas flows through the pressure let-down sonic nozzle (1.782" throat diameter) coated with stellite for erosion protection. The pressure drops to atmospheric across the nozzle and the hot gases are exhausted into the atmosphere. Tempering air can be injected into the flow gas stream upstream of the nozzle to maintain a desired bed pressure. The particles collected by the two cyclones fall down into a cyclone ash lockhopper system for disposal. Table 3-9 presents details of the flow gas system.

\subsection{Material Feeding System}

Coal and sorbent (limestone or dolomite) are fed into the combustor by individual lockhopper systems. Each lockhopper system consists of a bin to store enough solids for a considerable operating time, a lockhopper with inlet and outlet knife valves, a metering pocket valve and a feed pipe into the combustor. Tables 3-10 and 3-11 present details of coal and sorbent feed systems. Figure 3-8 presents the installed sorbent feeding system. 

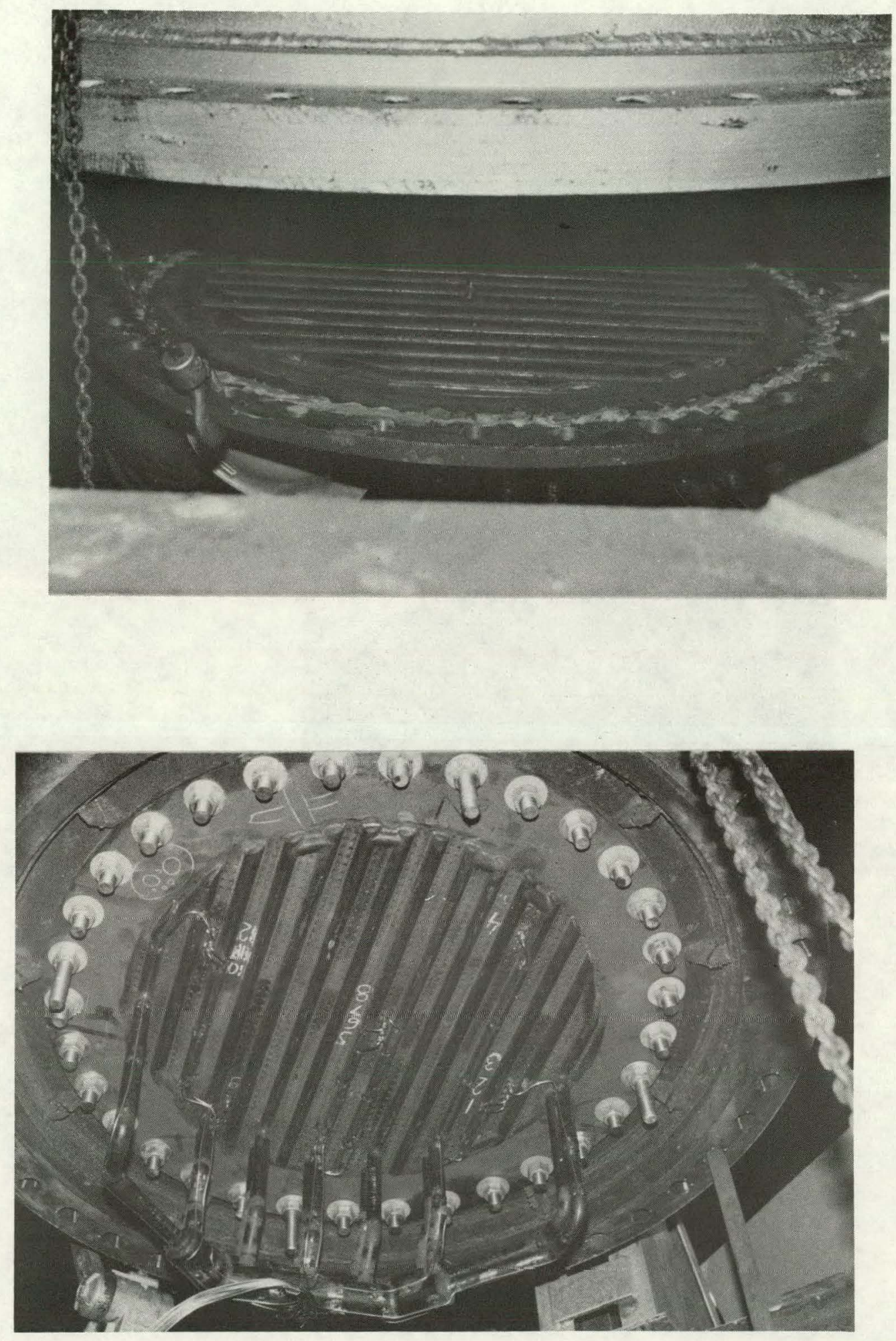

FIGURE 3.7 DISTRIBUTOR PLATE, TOP AND BOTTOM VIEWS 


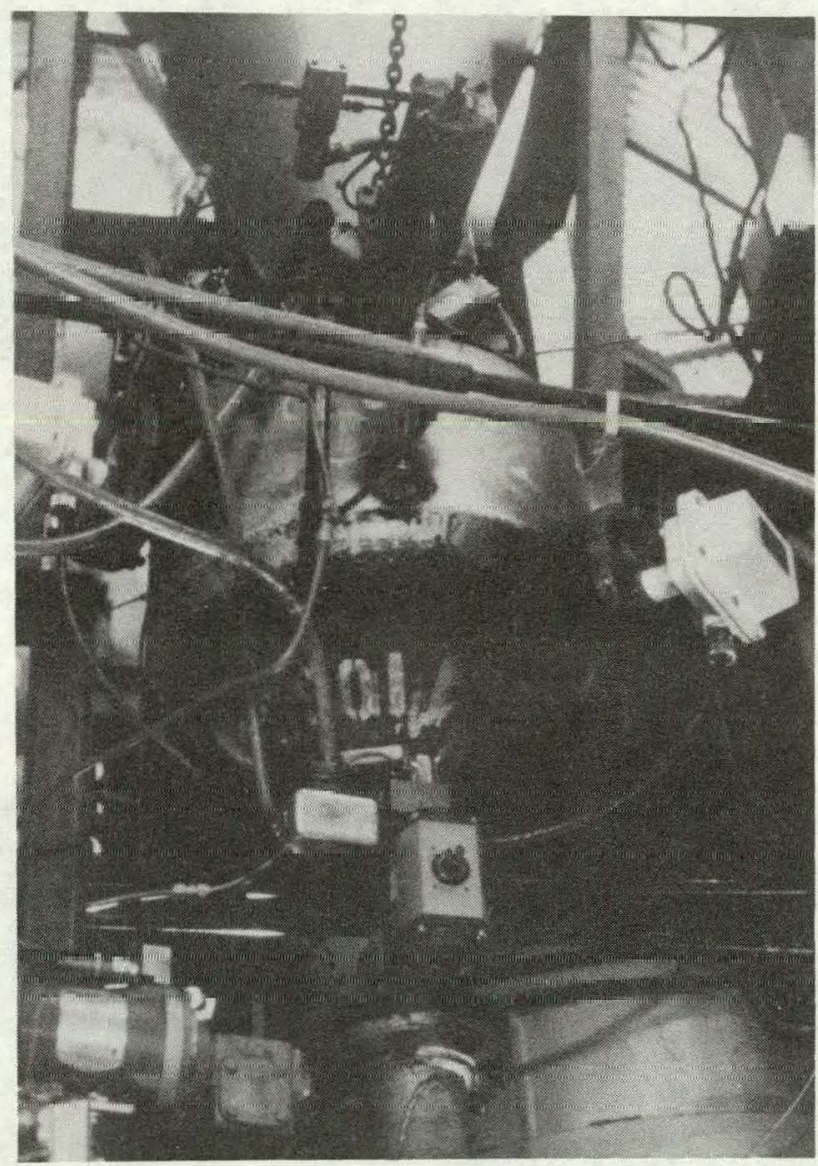

FIGURE 3.8 SORBENT FEED SYSTEM 
Table 3-8

Combustor System Design Data

1. Lower Plenum Chamber

Shell OD:

Height:

Inside Diameter:

Refractory Firebrick:

Insulating Castable:

Inclination of Burner at

Entry into Shell:

Location of Burners:

Fluidizing Air Inlet:

Pressure Tap Ring:

2. Dis.tributor Plate

Thickness:

Material :

Total Number of Holes:

Hole Diameter at Downstream:

Hole Diameter at Upstream:

Longitudinal Pitch:

Transverse Pitch:

\% Open Area:
40 in $\times 0.4$ in

37.5 in

30.7 in

Altex 85-B, $41 / 2$ in Thick

Litecast 50, $33 / 4$ in Thick

$15^{\circ}$ to horizontal, flame downward

28 in Below Grid

62 in Below Grid

50 in Below Grid
1 in

Carbon Steel

1132

0.11 in ( $3 / 8$ in Long)

$3 / 16$ in (5/8 in Long)

0.61 in

0.5 and $1 / 55$ in

1.45 
Table 3-8 Cont'd

Jet Velocity (o $4 \mathrm{ft} / \mathrm{sec}$ Fluidizing Velocity and $1600^{\circ} \mathrm{F}$ Bed Temperature:

Coolant Tube OD $\times t$ (semi Circular):

Length of Cooling Tube:

Connlant (water) Flnw

Required:

Water Temperature Rise:

Water Pressure o Inlet:

Water Pressure o Outlet:

3. Combustor and Freeboard

Shell กุ $x$ t:

Inside Diameter (with

Refractory Lining):

Height of Combustor and

Freeboard Section:

Openings in the Combustor

Shell Windows:

Instruments Ports:

Refractory Lining-

FIre Brick:

Insulating Brick:

Particle Sampling Ports

in Freeboard:
$70 \mathrm{ft} / \mathrm{sec}$.

1.05 in $\times 0.154$ in

$30.23 \mathrm{ft}$

$5 \mathrm{gpm}(2500 \mathrm{ib} / \mathrm{m})$

$70^{\circ} \mathrm{F}$ to $230^{\circ} \mathrm{F}$ \& $1600^{\circ} \mathrm{F}$ Bed Temperature

50 psig

35 psig (min)

48 in $x \cap, 4$ in

30.7 in

244 in

20,4 in $\phi$

30. 1 in $\phi$

Alt tex $\overline{8} \overline{5}-B$ (Grefco

GR 2300 (Grefco)

4 in, $11 / 2$ in $\phi$ 


\section{Table 3-8 cont'd}

Reducing Cone

Height:

Inside Diameter at Top

of the Section:

Inside Diameter at

Bottom of the Section:
22 in

12 in

30.7 in 
Table 3-9

Flue Gas System

A. Particulate Control System

Primary Cyclone: Lined with 6 inches of Litecast 50 and $316 \mathrm{SS}$ liner, $70 \mathrm{ft} / \mathrm{sec}$ inlet velocity, 6 in wg pressure drop, $87 \%$ velocity.

Secondary cyclone:

lined w1th 5 in of Lltecasl 50 $140 \mathrm{ft} / \mathrm{sec}$ inlet velocity, $18 \mathrm{in}$ wg pressure drop, $69 \%$ efficiency.

Total System Efficiency: $\quad 96 \%$

B. Pressure Let-Down System

Pressure Reducing Nozzle: 1.782 in throat diameter, 304 SS, stellite coating

Piping:

16 in OD, wi th Litecast 50 lines and 8 in 316 SS liner. 


\section{Table 3-10 \\ Coal Feed System}

Coal Bin:

No. of Lockhoppers:

Lockhopper:

Lockhopper Val ves:

Coal: Pocket Valve

Pneumatic Feed Nozzle:
48 in OD, 86 in $\mathrm{High}, 92$ cubic $\mathrm{ft}$ volume capacity $(\simeq 45001 \mathrm{~b})$

\section{2}

18 in 0D, 64 in High, 7.25 cubic ft volume capacity $(\approx 3601 \mathrm{~b})$

6 in DeZurik Knife Valves

5 Pockets of 13 in $^{3}$ volume capacity each, 65 in $^{3}$ total volume

$2.5 \mathrm{in}, 50$ in long, 10 in above grid, a ring at nozzle and cools the pipe projecting into hot bed 


\section{Table 3-11 \\ Sorbent Feed System}

Sorbent Bin:

46 cubic $\mathrm{ft}$ volume capacity $(\simeq 45001 \mathrm{~b})$

No. of Lockhoppers:

Lockhopper:

4 cubic ft volume capacity ( $\simeq 4$ 4nก门 $)$

Lockhopper Valves:

4 in inlet and 2 in outlet DeZurik Knife Valves

Sorbent Pocket Valve:

5 pockets of $3.2 \mathrm{in}^{3}$ each, 16 in $^{3}$ total volume

Gravity Feed Pipe:

3 in $\phi$ 


\subsection{Instrumentation and Controls}

The PFBC facility is provided with a number of thermocouples, pressure taps, and flow meters to monitor the combustion process and gather data for performance analysis. A total of 48 thermocouples measure the gas stream temperatures, metal surface temperatures, and the water temperatures. A total of 25 pressure taps facilitate measurement of absolute and differential pressures in the gas stream. Venturi meters and rotameters are provided for air and water flow measurement, respectively.

Dust sampling stations are provided at three locations viz. exit points of the combustor, primary cyclone, and secondary cyclone. Conventional isokinetic sampling is performed and the dust collected on Balston filters will be analyzed. Gas sampling stations are also provided at three locations in the gas stream, and the on-line analysis includes $\mathrm{SO}_{2}, \mathrm{O}_{2}, \mathrm{CO}, \mathrm{CO}_{2}$ and $\mathrm{NO}_{x}$.

The facility is provided with remote manual controls for initial testing. A complete automatic control system is envisioned for the facility at a later date during the test program.

The fluidizing air control valve can be adjusted to obtain the desired pressure or desired mass flow in the bed. This is made possible by the sonic flow nozzle, downstream of the secondary cyclone, which is designed to produce the desired pressure at a single mass flow rate. Fine control of the bed pressure is effected by tempering air introduced upstream of the sonic nozzle. These valves are all actuated remotely from the control room.

Coal and sorbent feed are provided by two identical variable speed DC drive systems. They are independently controlled by the operator by means of 10 turn speed potentiometers. The speed range (read by digital tachometers) of 1-20 rpm is sufficient for all firing rates and $\mathrm{Ca} / \mathrm{S}$ ratios contemplated for the facility.

Safety interlocks are incorporated for coal feed interruption and alarm indication for bed temperature, bed pressure, water temperature and pressure.

Lockhopper control systems for the five lockhoppers embody several common features: automatic-manual mode selection, four operating states (depressurization, empty/fill, pressurization, fill/feed), interlocks to preclude out-of-sequence operation, and, for the auto modes, pressure and fill/feed logic fault alarms. The coal and sorbent lockhoppers have a hi-lo point level indicator/operation whereas the cyclone dust and bed drain lockhoppers operate on a time basis. 
4. Data Acquisition

Data acquisition is accomplished by a Doric Digitrend 220 logger and two Honeywell Visicorders. The former is essentially used for temperature data and the latter for pressure data.

\subsection{Digitrend 220 Data Logger}

A Doric Digitrend 220 data logger is used to record 48 temperature readings, two pressure differential readings for air flow measurements, two speeds of solid feeder motors and 5 gas analysis data. The print out of the above 57 data are available every ten minutes during operation. This time interval can be adjusted depending on the requi rements.

\subsection{Visicorders}

Two multi-channel (36) visicorders are used for recording important variables during operation. Some pressure data are plotted on one of the visicorders. Two scani valves are used for reading 15 pressure differentials and four absolute pressures at definite intervals of time. The details of measurements are given in Table 4-1. 
Table 4-1

Data Acquisition

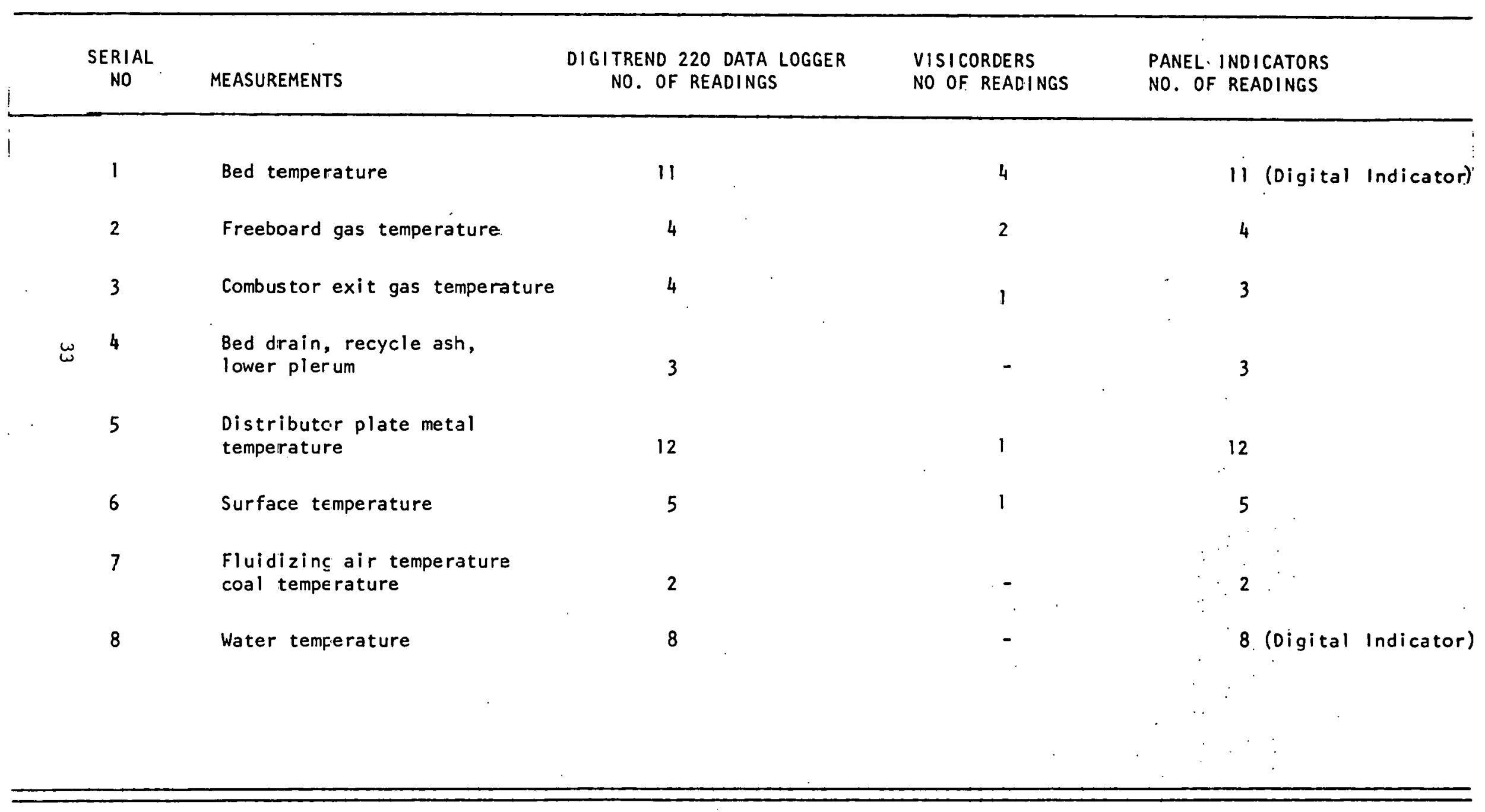


Table 4-1 (Cont'd)

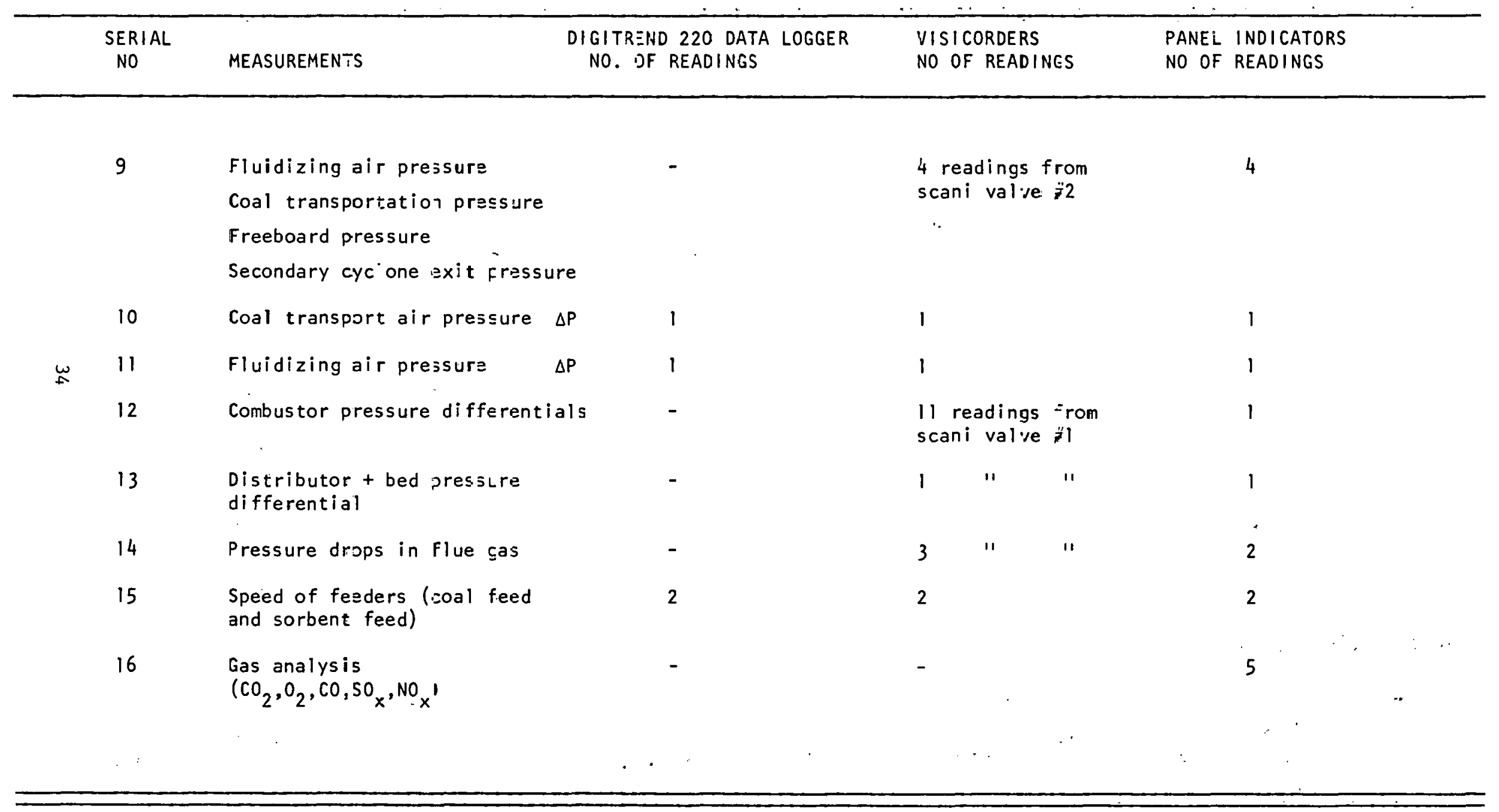


5. Prequalification Checkout

5.1 Instrumentation Check List - See attached list at the end of this section.

\subsection{Individual Equipment/Component Check}

\subsubsection{Compressor}

Compressed air for the bed is provided by two-Gardner-Denver diesel-driven compressors. Each is rated at $1600 \mathrm{cfm}$ of air at $100 \mathrm{psig.}$ compressor discharge temperature if about $145^{\circ} \mathrm{F}$. The compressor and the other components., namely, the engine, fuel system, air filters, electrical system and radiator will be checked before starting the compressor. The following checkout tests will be performed upon installation of the compressor:

1) Compressors will be operated for determining the quality of oil carry-over. If oil carry-over is detected, compressor will be re-adjusted according to the compressor service manuat.

2) Compressor auto start feature will be checked by allowing exhaust pressure to drop below the set point.

3) Flow and pressure stability of the compressor will be evaluated by noting compressor characteristics over a period of time and comparing it with the manufacturers specifications.

\subsubsection{Pressurization Test of Air Dislribution Syslem!}

The air circuit including the main air header from the compressor will be checked for any leaks by closing all valves at the outlet of the main air header and pressurizing the circuit to $150 \mathrm{psia}$. Any leaks identified should be corrected and the systems should be rechecked.

\subsubsection{Combustion A1r System}

This test includes the main air lines and the combustor. The air blowers which supply air to the main air line will be tested, and 
the characteristics (pressure vs flow) will be checked. The exit of the combustor will be closed and the combustor, including the fluidizing air lines, cooling air lines and preheat burner air lines, will be pressurized to 150 psia and the whole system checked for leaks. System pressurization rates will be checked for at least 4 valve positions of the main flow control valve (FCV). Depressurization rates wili be checked by using the pressure let-down system. The venturi downstream of the FCV will be checked for its characteristics.

\subsubsection{Auxilliary Air System}

The air circuit comprising the sorbent lockhopper, sorbent feed line, coal lockhopper, coal feed lines, dust lockhopper, bed drain lockhopper, and the primary and secondary cyclones will be pressurized to $150 \mathrm{psia}$ and tested for any leaks. Any leaks detected will be corrected and the system rechecked.

\subsubsection{Coal and Sorbent Feeder Calibration}

The coal and sorbent feeders have the following specifications:

Coal Feeder

Volume Displacement per

revolution (inch $3 / \mathrm{rev}$ )

Mass Displacement per

revolution ( $\mathrm{lb} / \mathrm{rev})$
55.0

1.595

$$
\left(\rho_{B}=50 \# / \mathrm{ft}^{3}\right)
$$

Sorbent Feeder

Rotary feeders will be calibrated over the range of speed by following the procedure.

\subsubsection{Preheat System}

The gas burners will be started and adjusted according to the following procedures:

1. Close all fuel shut-off valves. Close limiting orifice gas valves on initial lighting. Open furnace/combustor vents. 
2. Start the blower and check direction of rotation.

3. Open burner air valves wide and purge the chamber.

4. The air control valves should be adjusted to lowfire position.

5. Light pilots according to instructions given in the service manual.

6. Using a screw driver, open the limiting orifice a few turns counter-clockwise. Open air shut-off valves. If the burner does not light, close the gas shut-off valve and open the limiting orifice a few turns more. Purge the chamber and open the gas shut-off valve. Repeat this procedure until the flame lights. Adjust as needed while slowly turning the main air valve to high fire. Replace the cover on the limiting orifice gas valve.

7. To adjust burner to low-fire positions, return the air control valve to low-fire position without changing limiting orifice setting. Adjust gas/air ratio regulator for desired flame. The spring adjusting plug of the \#7218 regulator should be turned clockwise for more gas and counter-clockwise for less gas.

8. Turn both burners to high fire. If necessary, adjust the limiting orifice gas valves.

9. Turn both burners to low-fire and shut it off.

\subsubsection{Kerosene Injection System}

The kerosene injection system consists mainly of a nitrogen blanketed kerosene tank, kerosene supply line, nitrogen purging line, air supply line and a line leading the kerosene vapor-air mixture to the injector.

The whole circuit will bc pressurized to 150 psig and tested for leaks. The calibrations of the rotameters and pressure indicators will be checked. The functional aspects of the pressure regulator, solenoid valves, check valves, etc. will be checked. 
The kerosene tank will be purged completely with nitrogen and filled. Using the vent on the tank, the desired pressure can be maintained in the tank. The operational aspects will be checked during coal firing tests. 


\section{INSTRUMENT CHECK LIST}

Prior to ignition and fluidized tests, all the instruments for measuring the temperature, pressure and flow have $=0$ be checked for proper functioning. The continuity and readiness of ali alarms, switches, lights, interlocks and relays will have to be checked. The instruments are to be checked individually. The details of the check list are as follows:

$\begin{array}{llll}\text { SERIAL \# INSTRUMENT LOCATION/PURPOSE } & \text { NO. OF } & \begin{array}{c}\text { CHECKS } \\ \text { AFTER PROCUREMENT }\end{array}\end{array}$

1 Thermocouples 1. Bed material temp-
erature combustor

K Type 33

and in lockhoppers

2. Flue gas temperature

3. fish temperature

4. Mietal Temperature

5. Water Temperature

$\omega$

$J$ Type

8

T Type

7
Flow Meters

Venture for flow measurement

Indicators

Alarms
I. For bed cooling water

2. For distributor cooling water

Measurement of coal transport and fluidizing air flow.

Temperature, pressure gas analyses

1. Bed temperature
Continuity

7

Calibration

- Measuring point position.

Dimensional accuracy

Calibration

Calibration 


\section{Start-Up Procedure}

The unit start-up procedure is given below.

\subsection{Initial Bed Height for Start-Up}

1. Check the static bed height through the window $E-1$ by visual ubservalion. If the bed height is less than 19" (the height of window E-1), go to Step 2. It the bed height is grealer lhain $79^{\prime \prime}$, go to step 3.

2. Open sorbent lock.hopper valve $\$ 2$ and run the sorbent feeder. Feed the sorbent till the bed height increases to the $E-1$ level.

3. Start the compressor and pump air into the air header.

4. Verify that header air pressure is 60 psig for atm tests, 75 psig for 4 atm tests, and 100 psig for 7 atm tests.

5. Open air valves $A 2, A 6, A 7, A 8, A 11, A 12, A 14$, $A 15$ and $A 16$.

6. Adjust. the regulating valves $A 3$ and Flo to ensure air flow through fluidizing and coal transport lines. Verify that a minimum flow of $300 \mathrm{lb} / \mathrm{hr}$ is maintained in the coal transport line.

7. Open valve A5 to fluidize the bed.

8. Check bed pressure drop. If it is about 1.2 psi (currespunding to a bed hcight of 19"), close valve $A 3$ and initiate gas preheat as explained in Section 6.2

9. If the bed pressure drop is less than $1.2 \mathrm{psi}$, feed sorbent material till it is reached. Initiate gas preheat (Section 6.2).

10. Fluidize the bed according to Steps 3 to 7 .

Drain the excess bed material by opening valve Fll till bed pressure drop is 1.2 psi. Close valves $\mathrm{F} 11$ and $A 3$, start gas preheat. 


\subsection{Gas Preheat}

1. Open valves $\mathrm{Cl}$ and $\mathrm{C} 2$

2. Check water flow through distributor plate cooling circuit by observing the flow meters. Maintain a minimum flow of $5 \mathrm{gpm}$ and a water outlet pressure of 35 psig.

3. Crack open air valve $A 3$ to establish air flow for burners.

4. Light gas burners (Refer to Gas Burners Operating Instructions).

5. Increase the air flow to raise the heat input capacity of burners.

6. Monitor flue gas temperature in preheat chamber. If the temperature is more than $1600^{\circ} \mathrm{F}$, immediately increase the air flow to reduce the temperature to $1600^{\circ} \mathrm{F}$. If the temperature is lower than $1200^{\circ} \mathrm{F}$, increase gas (fuel) flow to raise the temperature to $1600^{\circ} \mathrm{F}$. Under no condition shall the temperature be permitted to exceed $2000^{\circ} \mathrm{F}$.

7. Verify that the bed temperature shows an increasing trend. When the bed temperature approaches $800^{\circ} \mathrm{F}$, start kerosene preheat system as described in Section 6.3.

\subsection{Kerosene Preheat}

1. When the bed temperature approaches $800^{\circ} \mathrm{F}$, establish water flow in the bed cooling coils by opening val ves $\mathrm{C} 10, \mathrm{C} 4, \mathrm{C} 5, \mathrm{C} 6, \mathrm{C}, \mathrm{C} 8, \mathrm{C} 9$, and $\mathrm{C} 3$ in that order.

2. Actuate the kerosene burner by opening Valves $\mathrm{PI}$, $\mathrm{P} 38, \mathrm{P} 3 \mathrm{l}$, and other kerosene s.ystem valves. A rising trend in bed temperature shows that kerosene is combusting.

3. If the bed temperature shows a decreasing trend, switch off the kerosene supply and stop the coolant 
water flow through the heat exchanger. The bed temperature should increase since the gas burner is still on. (Repeat steps 1 and 2 until the temperature increases). With both gas and kerosene burners on, bed temperature should rise to $1200^{\circ} \mathrm{F}$ in about 10-15 minutes.

\subsection{Initiate Coal Flow}

1. When the bed temperature reaches $1200^{\circ} \mathrm{F}$, open valve F2 and actuate F9 to establish coal flow at a rate of 190-200 $\mathrm{hh} / \mathrm{hr}$. A fast rise in bed temperature shows that coal is combusting.

2. Switch off gas burner.

3. Gradually reduce kerosene supply while still maintaining a rise in bed temperature.

4. When bed temperature reaches $1400^{\circ} \mathrm{F}$ (in about $1 / 2$ hour), remove kerosene burner from service.

5. Reduce the coal flow rate to $110-120 \mathrm{lb} / \mathrm{hr}$ which is the approximate rate for stable operation at atmospheric pressure.

6. Adjust the air flow to $1500 \mathrm{lb} / \mathrm{hr}$ corresponding to $U \cong 4 \mathrm{ft} / \mathrm{sec}$ while malntaining $1400^{\circ} \mathrm{F}$ temperature.

\subsection{Build-Up to Test Conditions}

1. Start feeding bed material (sorbent) at a rate of $1100 \mathrm{lb} / \mathrm{hr}$ to raise bed level to test condition.

2. As the heat exchanger tubes are progressively immersed by the addition of bed material, increase coal and air flow rates simultanenusly, ensuring a rising bed temperature and pressure. (Pressure increases automatically because of the nozzle in the exhaust system).

3. Monitor the bed pressure drop. Upon reaching the desired bed pressure drop of 2.1 psi (corresponding to bed height of $6^{\prime}$ ), stop the sorbent feed. 
4. Adjust coal and air flow rates to achieve and maintain $1600^{\circ} \mathrm{F}$.

5. At this stage, the desired bed height and bed temperature, and the corresponding coal and air. flow rates have been established. The pressure also should be at desired value. If bed pressure is slightly lower, open the tempering air control valve G6. and regulate till the desired higher pressure is obtained. If bed pressure is slightly higher, no further control of input parameters is necessary.

6. Start feeding the sorbent at a rate corresponding to calculated $\mathrm{Ca} / \mathrm{S}$ ratio.

7. Adjust the coal and air flow rates to overcome temperature fluctuations greater $+20^{\circ} \mathrm{F}$. If the fluctuations are within $\pm 20^{\circ} \mathrm{F}$, no adjustment is necessary.

8. Maintain all flow rates constant to obtain steady state conditions. 


\section{Normal Operation}

below.

The valves operation during normal running of the unit is described

Valves to be kept open are the combustion air line valve (A2), shell cooling air inlet valve $(A 6)$, tempering air line valve $(A B)$, dust lockhopper air valve (A7), instrument air valve (A11), pressure tape purge air valve (A12), coal lockhopper air valve (Al5), kerosene injection air valve near the auxiliary system air distribution pipe (A14), sorbent lockhopper air valve (A16), heat exchanger water inlel (C3) and outlet valves (C4, C5, C6, C7, C8, C9, and CIU), utilities air valve (A10) and kerosene system air line valves (P1 and P2).

The distributor plate coolant inlet and outlet valves ( $\mathrm{Cl}$ and C2) may have to be operated if the distributor plate overheats. Otherwise these two valves are to be kept closed.

Other valves to be kept closed are those which isolate gas preheat system from high pressure air in the lower plenum (P6, P10, P11, P17a, P26, $P 30$ ) and combustion air bypass line valve (AI) and spare air trapping valve (A9).

Kemote or local regulatilly of flows are done by using valves in combustion air line (A3), coal transport air line (F10), sorbent feed line (S3), coal feed line (F9), and air bypass control line (A5) for combustor shell conltng.

The valves which follow automatic sequential 'open-close' operations at predetermined frequencies are those in lockhopper pressurizing circuits, viz. coal lockhoppers F1, F2, F3, F4, F5, F6, F7, F8, bed drain lockhopper F11, F12, F13, Fl4, sorbent lockhopper S1, S2, S5, S6, and cyclone dust rockhopper G2, G3, G4, G5 and G8.

The particle removal probe air line valve (Al3) is opened intermittently.

During normol running of the unit, the operation of valves in the gas and kerosene preheat system other than those mentioned earlier become void.

Provision is made to install an air circuit with Valve Al7 for the pneumatic sorbent feeding if it is required at a later date. The same approach is applicable on the use of spare (A9) and sorbent transport air regulating valves $(54)$. All the valves shall be frequently checked for leakage and proper operation. 


\section{Shutdown Procedure}

\subsection{Normal Shutdown}

1. Reduce coal feed gradually.

2. Reduce air flow correspondingly. (Bed Temperature is likely to remain constant since the bed pressure decreases simultaneously with decrease in air flow).

3. Reduce the coal and air flow rates to 150 and $1350 \mathrm{lb} / \mathrm{hr}$, respectively, at atmospheric pressure.

4. Stop coal and sorbent flow.

5. If bed temperature goes below $400^{\circ} \mathrm{F}$, slump the bed by closing air valve $A 3$.

6. Monitor the coolant inlet and outlet temperature. If there is no significant temperature rise $\left(\neq 5^{\circ} \mathrm{F}\right)$, stop the coolant circulation.

7. Stop all equipment.

8. If cold restart is expected, drain the bed material to $19^{\prime \prime}$ (Bed pressure drop $\simeq 1.2 \mathrm{psi}$ ).

\subsection{Emergency Shutdown}

1. Cut off coal and sorbent feed.

2. Close air valve $A 3$ thus depressurizing and slumping the bed.

3. Maintain coolant flow and minitor the coolant outlet and iniet temperature. If there is no significant temperature rise $\left(\ngtr 5^{\circ} \mathrm{F}\right)$, stop the coolant flow. 


\section{Restart}

\subsection{Cold Restart}

This refers to the condition of unit start-up whenever the bed temperature is below $1200^{\circ} \mathrm{F}$. When the bed temperature is between $800^{\circ} \mathrm{F}$ and $1200^{\circ} \mathrm{F}$, the restart procedure is as follows:

1. Maintain air flow at $1500-1800 \mathrm{lb} / \mathrm{hr}$.

2. Light up yas burner.

3. Matnlain lhe rlue yás temperature in the lower plenum chamber at $1200-1600^{\circ} \mathrm{F}$.

4. Activate the kerosene burner.

5. When the bed temperature reaches $1200^{\circ} \mathrm{F}$, start coal flow.

6. Keep the valves at the positions described under "start-up" (Section 6.0).

When the bed temperature is below $800^{\circ} \mathrm{F}$, the restart procedure is as follows:

1. Cut off heat exchanger water supply.

2. Light up the gas burner.

3. Follow the procedure given under Section 6.0 "start-up" procedure.

\subsection{Hot Restiart.}

This refers to the condition when the bed is restarted at temperatures $1200^{\circ} \mathrm{F}$ and above.

1. Start fluidizing air flow at 1500-1800 $\mathrm{lb} / \mathrm{hr}$ by opening valve $A 3$.

2. Simultaneously start the coal feed at $190-200 \mathrm{lb} / \mathrm{hr}$. 
3. The bed temperature should be increasing. If not, slump the bed and restart after insuring that the bed temperature is still above $1200^{\circ} \mathrm{F}$.

4. If the bed temperature has fallen below $1200^{\circ} \mathrm{F}$, follow the procedure given under "cold restart".

5. If the bed temperature is increasing, follow the guidelines given under Section 6.0 "start-up" procedure, subsections 6.4 and 6.5 . 
10. Process Abnormalities

10.1 Pressure Failure in Combustor
Causes:
a) Failure of exhaust system nozzle
b) Compressor trip
c) Failure of air control valve $A 3$
d) Pressure relief patch burst
e) Breakage of a combustor window
Indication:
M arm/Annunciation
Remedial Action:
Emergency Shutdown

10.2 Excess Pressure Build-up ( $\simeq 150 \mathrm{psig}$ ) in Combustor
Causes:
a) Exhaust line blockage
b) Excessive supply of air from storage banks because of failure of pressure reducing station.
Indication: $\quad A l a r m / A n n u n r i a t i o n$
Remedial Action: Emergency Shutdown

10.3 Low Bed Temperature $\left(<1400^{\circ} \mathrm{F}\right)$
Causes:
a) Leak in heat exchanger
b) Insufficient coal/air supply
c) Expanded bed height lower than design value.
d) Htgh motsture in codl
Indication:
Alarnil/Annunciation
Remedial Action:
a) Emergency Shutdown
b) Purge system immediately. 
10.4 High Bed Temperature ( $\left.>1850^{\circ} \mathrm{F}\right)$
Causes :
a) High coal flow rate
b) Failure of bed cooling water
c) Reduction in air flow rate
d) Clinker formation resulting in localized overheating.
Indication:
Alarm/Annunciation
Remedial Action:
Emergency Shutdown

10.5 Bed Height Build-up.
Causes:
Failure of bed drain system by line blockage
Indication:
Increased bed pressure drop
Remedial Action:
Emergency Shutdown

10.6 High Distributor Plate Pressure Drop
Causes:
Blockage of distributor openings
Indication:
Al arm/Annunciation
Remedial Action:
Emergency Shutdown

10.7. Equipment Fallure

10.7.1 Coolant Pump Failure

Indication:

Alarm/Annunciation

Remedial Action:

a) Restart the pump.

b) If the pump does not start, shut down the unit as under "Emergency Shut down 


\subsubsection{Compressor Failure}

Indication:

Alarm/Annunciation

Remedial Action:

a) Restart the compressor

b) If the compressor does not start, switch to 'storage bank air supply.'

c) If the storage bank air supply is not available, shut down the unit as under "Emergency Shutdown."

10.7.3 Solfd Handling/Feed System Failure

Indication:

Remedial Action:

\section{Alarm/Annunciation}

Most of the time, it should be possible to assess the severity of the problem. If solids feeding cannot be reestablished, shut down as under."Normal Shutdown.". If the problem becomes acute, shut down the unit as under "Emergency Shutdown." 
11. Safety Provisions and Procedures

Several important features provided on the PFBC facility are explained in the following paragraphs.

\subsection{Air System}

Safety Provision: The storage air is at 2000 psig whereas the pressure vessel design pressure is 132.9 psig. To protect the combustor vessel and other pressure parts from being accidentally pressurized to 2000 psig, a pressure rellef patch is provided integral with the pressure reducer.

\subsection{Preheat System}

\subsubsection{Gas System}

Safety Provision: During start-up, the gas flow will be cut off if there is no flame within 10 secs. An audible alarm will go on indicating a non-start condition.

Safety Procedure: The burner can not be restarted without purging the system. The gas (flame) temperature will be monitored carefully. In no case shall the flame temperature be allowed to exceed $1700^{\circ} \mathrm{F}$.

\subsubsection{Kerosene System}

Safety Provision: An interlock is provided linking the bed temperature and kerosene injertion. The kerosene cannot be injected until the bed temperature is more than $800^{\circ} \mathrm{F}$.

Safety Procedure: The kerosene injection shall be turned off if the bed temperature shows no increase.

\subsection{Combustor System}

Safety Provistons: (1) A pressure relief patch with a bursting pressure equaling the maximum working pressure is provided on the reducing cone. The patch opens into the exhaust pipe on the downstream side of the pressure reducing nozzle. (2) Though the shell temperature is not expected to increase over $200^{\circ} \mathrm{F}$ with properly cast/built refractory materials, 
it is possible that refractory may crack or fall out leading to exposure of shell material to high flue gas temperatures. To overcome this problem, air cooled tubes are installed inside the shell periphery. A temperature sensitive paint on the shell should help the operator to identify the hot spots. (3) "Hi-LO" bed temperature alarms are provided to indicate $1800^{\circ} \mathrm{F}$ and $1400^{\circ} \mathrm{F}$ bed temperature limits. (4) "High $\Delta \mathrm{P}^{\prime \prime}$ alarm is provided for distributor plate pressure drop.

Safety Procedure: (1) If hot spots are detected on the shell, the operator shall reduce the operating pressure, stop the coal flow, and maintain air and water flow for bed to cool below $200^{\circ} \mathrm{F}$. (2) If the bed temperature exceeds $1800^{\circ} \mathrm{F}$, the facility shall be shut down. (3) When the "High $\triangle P$ " alarm goes on for the Uislributor plate, the facility will be shut down. Further start-up shall be done only after thorough cleaning of the clogged holes using compressed air jets.

\subsection{Heat Exchanger System}

- Safety Provisions: If the water inlet pressure goes below 40 psig, an al arm/annunciator will be activated.

Safety Procedure: (1) During the start of each test, the water circuit shall be checked for water flow through each circuit as indicated by the flow meters, pressure gage operation, and temperature indication. In case of tube burst or heavy leakage which can be detected by maximum water flow indication in one circuit, water hammering in a circuit and loss of bed temperature, water flow, coal flow and air flow shall be stopped in that order. (2) Immediate action avoids damage to refractories and possible corrosion of shell, distributor plate and heat exchanger surfaces. The combustor shall not be restarted unless thorough examination of refractory and distributor plate is completed. (3) If any water circuit shows abnormal rise (for example, $T_{\text {water }}=300^{\circ} \mathrm{F}$ ) in water temperature, the inlet valve shall be adjusted to increase water flow. If the water temperatue does not show a decrease, the unit shall be shut down. (4) The water inlet pressure shall not be less than 40 psig. If the water pressure goes below 35 psig even after the efforts to increase it, then the unit shall be shut-down dllowing the low pressure water flow to continue.

\subsection{Material Feeding System}

Safety Provisions: (1) Temperature sensitive paint is applied at selected points on the coal feed pipe. (2) Two exhaust fans are provided in the combustor area to prevent accumulation of dispersed dust. 
Safety Procedures: (1) Sudden pressure drop measured with a $\Delta P$ transducer at the pocket metering valve due to leakage - the valve shall be stopped and the two knife gate values at the upstream of the valve shall be closed. This ensures preventing hot high pressure gas from entering the lockhopper system from the combustor. (2) The air flow through the coal transport line shall be maintained at a presnet level. Low flow even at high system pressure may lead to settling of coal particles and choking of the line.

\subsection{Flue Gas System}

ture sensitive paint.

Safety Procedure: All flanged points vulnerable to high temperature, high pressure gas leaks shall be inspected periodically.

\subsection{General}

Safety Provisions: Signboards will be provided at appropriate locations indicating hot surfaces and potentially dangerous areas. Fire Extinguishers will be provided as required by the fire code. Exhaust fans are provided for ventilation.

\subsection{Safety Regulations for Personnel}

The following are the safety regulations to be adhered to while operating the facility.

1) During test runs, all staff and visitors will wear safety hats.

2) During test runs, all staff will carry eyeshields and aspirators and the personnel involved in any of the following duties will wear them: (a) coal feeding (b) sorbent feeding (c) solids disposal from pressure vessels and (d) any dust sampling or gas sampling activities on the combustor.

3) It is expected that the staff shall perform work in their allotted area. Unit operator's permission is required if they are to work in another area. 
4) Attempts to clear blockages in solid feeding lines, dust. sampling lines, gas sampling lines, coal and sorbent bins or in pressure tappings must be made by two members of the staff.

5) While the plant is being operated at high pressure, the following restricted areas are not to be entered without the approval of the unit operator: a) combustor platform, b) combustor (lower plenum) pit, c) cyclone support level platform (area near pressurerelief patch).

6) During operation of the plant under hot conditions (at any pressure), the working areas shall be adequately ventilated. All openings on the facility enclosure panels will be kept open unless otherwise required. Proper ventilation will be provided to assure elimination of coal or sorbent dust. Fire extinguishers must be provided near the gas and kerosene storage areas.

7) There shall always be direct communication between combustor ground level platform and control room. The walkway between the two locations shall be kept free of any obstructions at all times.

8) In the event of an unknown occurrence, the facility evacuation alarm will be sounded. Access to actuate this alarm will be provided at several suitable locations. All staff should be familiar with emergency evacuation paths and procedures.

9) No welding or work involving open flames will be undertaken at any time without consulting the unit operatur.

10. Staff carrying our measurements on the combustor platform must do so in pairs.

11. All visiturs will be accompanied by an NYU representative. 
